\title{
Az osztott dózisú trimodális kezelés első hazai alkalmazása nagy kockázatú húgyhólyagdaganat esetében
}

\author{
Fazekas Fruzsina dr. ${ }^{1}$ - Bíró Krisztina dr. ${ }^{2}$ \\ Ágoston Péter dr. ${ }^{3}$. Nagyiványi Krisztián dr. ${ }^{2}$. Gonda Gábor dr. ${ }^{4}$ \\ Buzogány István dr. ${ }^{1}$. Beöthe Tamás dr. ${ }^{1}$ \\ 'Péterfy Kórház-Rendelőintézet és Manninger Jenő Országos Traumatológiai Intézet, \\ Urológiai-Sebészeti Osztály, Budapest \\ ${ }^{2}$ Országos Onkológiai Intézet, Urogenitális Tumorok és Klinikai Farmakológiai Osztály, Budapest \\ ${ }^{3}$ Országos Onkológiai Intézet, Sugárterápiás Centrum, Budapest \\ ${ }^{4}$ Péterfy Kórház-Rendelőintézet és Manninger Jenő Országos Traumatológiai Intézet, Patológiai Osztály, \\ Budapest
}

\begin{abstract}
Az izominvazív vagy nagyon nagy kockázatú, felületes hólyagdaganatok kezelésének arany standardja a radikális húgyhólyag-eltávolítás (cystectomia). Válogatott betegek esetében hasonló hatékonyságú kezelés lehet az osztott dózisú (split-course) trimodális terápia, az endoszkópos tumorreszekció és a kemoirradiáció megszakított ciklusokkal történő alkalmazása. A split-course trimodális terápia a radikális cystectomiához hasonló eredményességú, a későbbi életminőség szempontjából pedig ígéretes kezelési lehetőség lehet megfelelően kiválasztott betegek esetében. Hazánkban első alkalommal végzett kezelést ismertetünk a téma szakirodalmi áttekintése mellett. A húgyhólyagtumor transurethralis reszekciója, maximális eradikációja után kemoirradiáció kezdődik, melyet 45 Gy sugárdózis elérésekor ismételt szövettani mintavétel szakít meg. Negatív szövettani eredmény esetén a megkezdett terápia a teljes dózis eléréséig folytatandó. Amennyiben a reszekció során élő tumor észlelhető, a radikális mútét elvégzése javasolt. A korábban transurethralis daganatreszekción négyszer átesett 54 éves beteg lokális immunterápia utáni recidívájának szövettana pT1, 'high grade' urothelialis carcinoma volt. A jól informált, kiváló fizikális statusú beteg kérését figyelembe véve split-course trimodális kezelést végeztünk. Negatív 'staging' vizsgálatok után maximális endoszkópos reszekció, majd kemoirradiáció következett. A 45 Gy besugárzás elérésekor elvégzett ismételt mintavétel azonnal feldolgozott szövettana negatív eredményt mutatott, így késedelem nélkül folytatódott a kemoirradiációs kezelés. Az eddigi kontrollvizsgálatok alapján a beteg komplett remisszióban van. A split-course trimodális terápia a radikális hólyageltávolítás megfelelő alternatívája jól informált, gondosan megválogatott betegek esetében. A szervmegtartó eljárás jobb életminőséget eredményezhet, ugyanakkor a beteget feltétlenül tájékoztatni kell, hogy sikertelenség esetén a radikális mütét is szükségessé válhat. A kezelés sikeres menedzselése csak a társszakmák szoros, jól tervezett együttmúködésével lehetséges.
\end{abstract}

Orv Hetil. 2021; 162(50): 2017-2022.

Kulcsszavak: húgyhólyagdaganatok, trimodális kezelés, kemoradioterápia, cystectomia, életminőség

\section{The first experience in Hungary with split-course multimodal treatment in high risk bladder cancer}

While radical cystectomy remains the gold standard to treat muscle-invasive or very high risk superficial bladder cancer, well selected patients can be offered split-course multimodal treatment as a similarly effective alternative, combining endoscopic tumor resection and split-course chemoradiotherapy. In highly selected patients, split-course trimodality therapy can lead to survival rates comparable to radical cystectomy with better quality of life outcomes. We present our experience with split-course trimodality treatment used for the very first time in Hungary. Maximal transurethral resection of bladder neoplasm is followed by chemoradiotherapy with repeated bladder biopsy after 45 Gy of irradiation. With negative biopsy results, chemoirradiation should be continued until full dose given. Salvage cystectomy is recommended if viable tumor is detected. Our patient (54), who previously underwent four transurethral bladder tumor resections and local immunotherapy, presented with pTl, high grade urothelial carcinoma 
recurrence. The well-informed, high performance status patient opted for split-course trimodality treatment. After negative staging scan results, the patient underwent complete endoscopic tumor eradication, followed by chemoradiotherapy. After 45 Gy of irradiation, repeated bladder biopsy was performed. The immediate histopathological examination found no viable tumor, therefore chemoradiotherapy was completed. Follow-up examinations suggest our patient in complete remission. Split-course trimodality treatment can be offered to well-informed and selected patients as a reasonable alternative to radical cystectomy. Though the bladder-sparing approach results in better quality of life, patients must know that in the case of treatment failure, radical cystectomy will likely be offered. Excellent multidisciplinary cooperation is a key to conduct this treatment alternative successfully.

Keywords: urinary bladder neoplasms, combined modality treatment, chemoradiotherapy, cystectomy, quality of life

Fazekas F, Bíró K, Ágoston P, Nagyiványi K, Gonda G, Buzogány I, Beöthe T. [The first experience in Hungary with split-course multimodal treatment in high risk bladder cancer]. Orv Hetil. 2021; 162(50): 2017-2022.

(Beérkezett: 2021. február 21.; elfogadva: 2021. április 5.)

\begin{abstract}
Rövidítések
BCG $=$ Bacillus Calmette-Guérin CTPS $=$ Cancer and Treat ment Perception Scale; EAU $=($ European Association of Urology) Európai Urológiai Társaság; ECOG $=($ Eastern Cooperative Oncology Group) Keleti Kooperatív Onkológiai Csoport; EORTC $=$ (European Organisation for Research and Treatment of Cancer) Európai Rákkutatási és Kezelési Szervezet; EPIC $=$ Expanded Prostate Cancer Index Composite; ESMO = (European Society for Medical Oncology) Európai Klinikai Onkológiai Társaság; HG = (high grade) magas gradusú; IMRT $=$ intenzitásmodulált radioterápia; $L G=($ low grade $)$ alacsony gradusú; $\mathrm{MGH}=($ Massachusetts General Hospital $)$ Massachusetts állam Centrumkórháza; MIBC = (muscle-invasive bladder cancer) izominvazív hólyagrák; QOL = (quality of life) életminőség; R0 = maradék daganattól mentes; $\mathrm{SC}=$ (split-course) osztott dózisú; TCC = (transitional cell carcinoma) átmeneti sejtes carcinoma; TUR = transurethralis reszekció
\end{abstract}

$\mathrm{Az}$ urothelialis carcinoma kezelését elsősorban a daganat mélységi terjedése határozza meg [1]. Felismeréskor a hólyagdaganatok 70\%-a ún. nem izominvazív, Ta, Tis vagy $\mathrm{Tl}$ klinikai stádiumba tartozó betegség. A nem izominvazív hólyagdaganatok általában endoszkópos mütét és lokális kemo- vagy immunterápia alkalmazásával sikeresen kezelhetők, ilyenkor a húgyhólyag eltávolítása ritkán válik szükségessé [2].

Ha a daganat eléri a hólyagfal izomzatát, vagy a nem izominvazív tumorok nagy progressziós rizikóval járó, recidív eseteiben radikális hólyagkiirtás válik szükségessé. A szervmegtartó alternatívát jelentő irradiáció, kemoirradiáció vagy szisztémás kemoterápia eredményessége elmarad a radikális mútététől $[3,4]$. A kezelési arany standard jelenleg a beteg szervezet számára sokszor jelentősen megterhelő radikális cystectomia [5-7]. A radikális műtét során a húgyhólyag, a kismedencei nyirokcsomók, nők esetében a méh, a petefészkek és a hüvely egy része, férfiaknál pedig a prosztata és az ondóhólyagok is eltávolításra kerülnek. A vizelet elvezetését új úton kell megoldani, amire több vizeletdeviációs eljárást dolgoztak ki $[8,9]$.

Az Európai Urológiai Társaság (EAU) irányelvei szerint gondosan szelektált, jól informált betegek csoportjában javasolható a három különböző kezelési modalitást, azaz a transurethralis reszekciós (TUR) mútétet, a kemoterápiát és az irradiációt kombináltan alkalmazó, szervmegőrző eljárás: a trimodális terápia [10]. A trimodális kezelés esetében a cél a szervmegtartás és a jobb életminőség elérése a kedvező túlélési esély megőrzése mellett. A trimodális kezelés sikertelensége, azaz a teljes patológiai tumoros remisszió elmaradása vagy a kezelést követő daganatkiújulás esetén, amennyiben a beteg arra alkalmas általános állapotban van, radikális, ún. salvage cystectomiát kell végezni. Erre a megoldásra Giacalone és mtsai tapasztalatai szerint az esetek 16\%-ában kerülhet sor [11]. Mindezek mellett a trimodális terápiával kezelt betegek negyedében kialakuló, nem izominvazív recidívák Sanchez és mtsai vizsgálata szerint 91\%-ban endoszkópos TUR-mútéttel, illetve lokális immunterápiával kezelhetők voltak [12].

Két fontos, egymástól lényegesen eltérő kemoirradiációs protokoll ismert a szakirodalomban. Az Egyesült Államokban használt, osztott dózisú (split-course, SC) protokoll esetében 45 Gy sugárdózis elérésekor a kezelés eredményességét ismételt transurethralis biopsziás mintavétellel kell ellenőrizni. Teljes remisszió esetén további 20 Gy besugárzással komplettálható a kezelés, pozitív szövettani eredmény esetén viszont a salvage radikális cystectomia elvégzése javasolt [13]. Az Egyesült Államok területén kívül használt protokoll szerint megszakítás nélkül adandó a teljes (55-65 Gy) sugárdózis. Fontos betegszelekciós szempont, hogy az SC trimodális kezelés csak olyan betegeknél javasolt, akik egyébként radikális cystectomiára alkalmasak, és szükség esetén el is fogadják a szerveltávolító mütétet. Az SC protokoll előnye, hogy nem teljes remisszió esetén kisebb sugárdózis leadása után végezhetjük el a radikális mütétet $[11,14]$. 
A teljes dózisú, köztes szövettani ellenőrzés nélküli eljárásnak legfóképpen a radikális cystectomiára alkalmatlan állapotú, illetve attól kategorikusan elzárkózó betegek csoportjában van jelentősége. Emellett szükség esetén a teljes kemoirradiációs dózis leadása után is végezhetünk salvage cystectomiát megfelelő fizikai állapotú betegeknél [8].

Tapasztalatunk szerint a multidiszciplináris, esetünkben több intézetben folyó, szigorú menetrendhez kötött kezelés menedzselése jelent igazán kihívást. A kezelés sikeréhez nélkülözhetetlen a társszakmák szoros, jól tervezett együttmúködése.

\section{Esetismertetés}

Hazánkban a rendelkezésre álló irodalmi adatok szerint első alkalommal végzett SC trimodális kezelés során szerzett tapasztalatainkat foglaljuk össze a téma szakirodalmi áttekintése mellett.

Az 54 éves, kiváló általános állapotú (ECOG 0), más intézetben összesen négy hólyagtumor-TUR-mütéten, illetve többszöri intravesicalis epirubicin- és BCG-kezelésen átesett férfi beteget radikális cystectomia végzése céljából irányították osztályunkra. Szövettani eredménye szerint betegsége a nagyon nagy progressziós kockázatú, nem izominvazív hólyagdaganatok csoportjába tartozott (BCG-refrakter pTl, cN0cM0 HG TCC).

A felsőfokú végzettségü beteg, aki a terápiás alternatívákról részletes orvosi felvilágosítást kapott, valamint a különböző lehetőségekről önállóan is gondosan tájékozódott, az SC trimodális kezelést kérte. Döntését azzal indokolta, hogy minél inkább aktív résztvevője kíván lenni saját kezelésének, gyógyulásának. Emellett tartott a radikális mútétből következő visszafordíthatatlan testi változásoktól is, de elfogadta, hogy a szervmegtartó kezelés sikertelensége esetén rákényszerülhetünk a radikális salvage cystectomia elvégzésére. Kontrasztanyagos mellkasi, hasi, medencei CT-vizsgálattal regionális vagy távoli áttét nem igazolódott. Az onkológiai kezelés megkezdése előtt az esetet onkológiai szakbizottság előtt ismertettük. Az onkoteam a kismedencei irradiáció közben elvégzett mintavétel várható szövődményei miatt nem javasolta a trimodális terápiát. Emellett az onkoteamtagok attól tartottak, hogy a több szakterület szoros együttmúködését igénylő terápiás terv megvalósítása akadályokba fog ütközni. A beteg kifejezett kérésére ismételt véleményt kértünk az onkoteamtől, amely a modern európai irányelveket figyelem előtt tartva végül az SC trimodális terápiát mint megfelelő kezelési alternatívát elfogadta. Ekkor az Országos Onkológiai Intézettel összefogva kezdődött meg a kezelés (1. ábra).

Első lépésben osztályunkon maximális hólyagtumorTUR-mútétet végeztünk. Egy apró, néhány milliméteres daganatrecidívát távolítottunk el a korábban operált területről, ezzel optikusan teljes reszekciót és daganatmentességet (R0) értünk el. A szövettani eredmény kis ma- lignitású, nem izominvazív urothelialis carcinoma volt (LG pTa TCC).

Betegünk ezt követően az Országos Onkológiai Intézetben 45 Gy kismedencei irradiációban részesült; a besugárzást 1,8 Gy gócfrakciókban kapta meg. A sugárterápia mellett összesen hét ciklus, ciszplatinalapú szisztémás kemoterápiás kezelést kapott. A kemoterápia tervezett heti dózisa $40 \mathrm{mg} /$ testfelszín $\mathrm{m}^{2}$ (80 mg/hét) volt, a kezelés végén a vérkép romlása miatt került sor dózisredukcióra.

45 Gy sugárdózis elérésekor a kemoirradiációs kezelést megszakítva mútéti körülmények között végzett urethrocystoscopia és az addigi kezelés eredményességét ellenőrző biopsziás mintavétel történt osztályunkon. Vizsgálatunkkor a hólyagkép negatív volt, daganatot, illetve a sugárkezelésből származó hólyagfali laesiót, sérülést nem találtunk annak ellenére, hogy a legutolsó kismedencei régiót érintő irradiáció mindössze két órával a mintavétel előtt fejeződött be. A beavatkozás nem bizonyult technikailag nehezebbnek, és vérzést sem tapasztaltunk. Az azonnal elvégzett, gyorsfagyasztásos eljárással feldolgozott szövettani minta élő daganatsejtet nem tartalmazott, amit a késóbbi részletes hisztopatológiai feldolgozás is megerósített.

A teljes remisszió ismeretében az Országos Onkológiai Intézetben további 20 Gy kismedencei besugárzással és a tervezettnek megfelelően folytatott kemoterápiával komplettáltuk a beteg kezelését. A terápia végére betegünknek Clavien-Dindo grade II-es, cystitis jellegú, irritatív vizelési ingerekkel járó panaszai alakultak ki, hasmenés és grade II-es enteritis mellett [15]. A kezelés megszakítása nem vált szükségessé az enyhe mellékhatások miatt. Betegünk gastrointestinalis panaszai a kezelés befejezésétól számított 14 napon belül enyhültek, irritatív vizeléses panaszai további 6 hónapig álltak fenn.

Betegünk a rendszeresen végzett flexibilis urethrocystoscopos kontrollvizsgálatok alapján recidívamentes. Az egyéves kontrollvizsgálat alkalmával urológiai panasza nem volt, spontán, jó sugárban, residuummentesen diurált, komplett remisszióban volt.

\section{Megbeszélés}

Az izominvazív vagy nagyon nagy kockázatú, nem izominvazív hólyagdaganatok szervmegőrző céllal történő, multimodális kezelése nem újdonság, a már korábban idézett Giacalone és mtsai vizsgálatában az 1986 és 2013 között kezelt betegek adatait és későbbi sorsát már elemezték. Az eredményességben igen jelentős javulást hoztak az évek, a nagyobb tapasztalat. Az 1986 és 1995 között elért, 66\%-os betegségspecifikus túlélés a 2005 és 2013 közötti időszakban 88\%-ra emelkedett. Ugyanezt a két időszakot összehasonlítva a sikertelen kezelés miatt elvégzett salvage cystectomiák aránya 42\%-ról 16\%-ra esett, holott a nagyobb stádiumban kezeltek aránya és a betegek életkora is emelkedett a második ciklusban [11]. Az eredmények alapján elmondhatjuk, hogy napjainkra a 


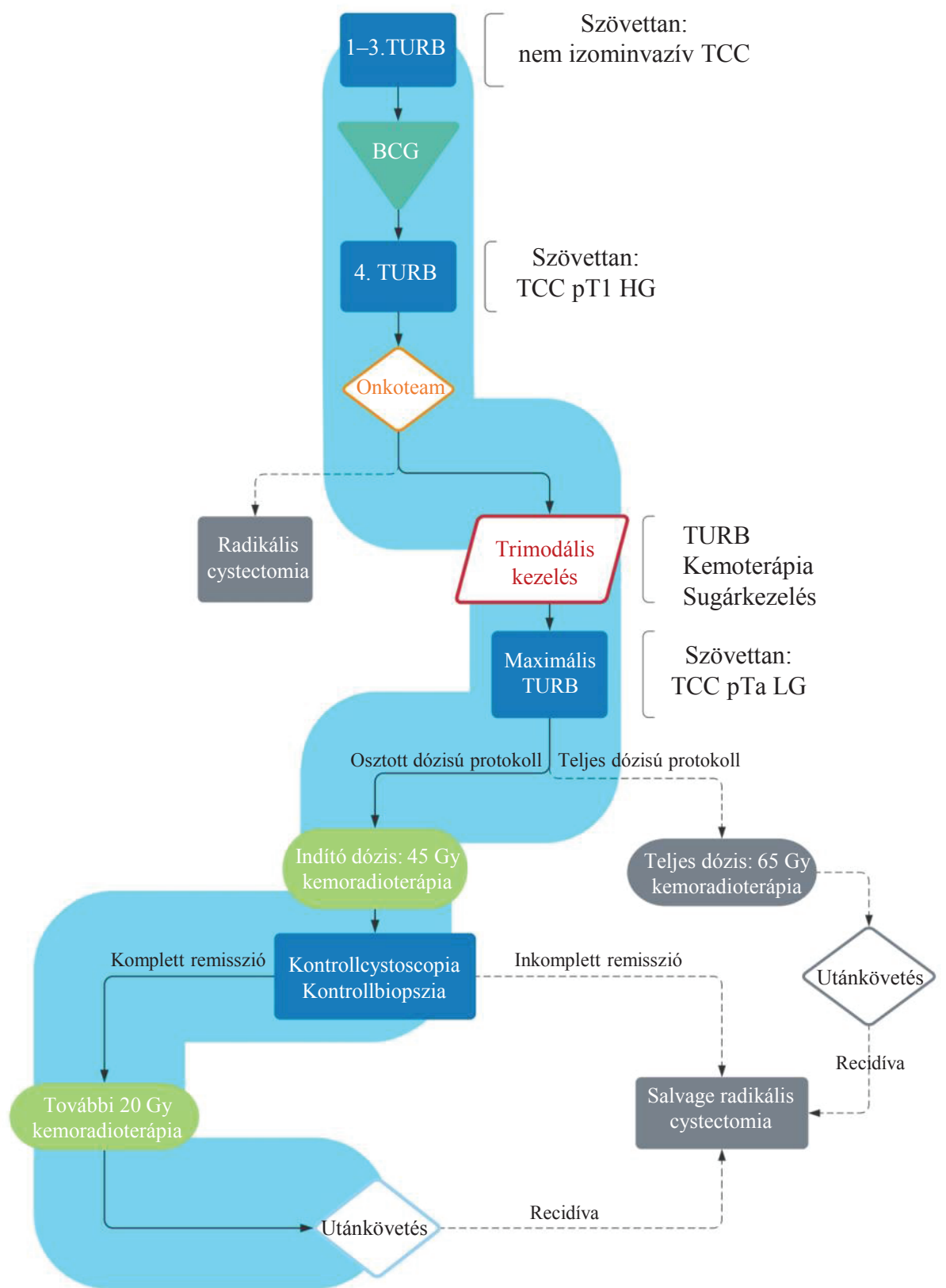

1. ábra

A trimodális kezelés folyamata a gyakorlatban

BCG = lokális Bacillus Calmette-Guérin kezelés; HG = magas gradusú; LG = alacsony gradusú; TCC = átmeneti sejtes carcinoma; TURB = hólyag daganat transurethralis reszekciója

trimodális terápia a betegségspecifikus túlélés és a kezelésre adott válasz szempontjából megfelelö, az arany standard radikális cystectomiával összehasonlítható eredményekre lehet képes $[8,11,16]$. A két eljárást közvetlenül összehasonlító prospektív vizsgálat ugyanakkor napjainkig nem történt, ami a végleges összehasonlító értékeléshez nélkülözhetetlen.

Elengedhetetlen, hogy a beteget a kezelés megkezdése előtt tájékoztassuk arról, hogy az SC trimodális terápia sikertelensége, tehát a kemoirradiáció alatt kapott pozitív szövettani lelet vagy későbbi daganatrecidíva esetén a salvage radikális cystectomia elvégzése szükségessé válhat [11]. Logikusnak tünik, és ezáltal a sebész és a beteg is joggal várhatja, hogy a salvage mútét a megelöző kezelések miatt technikailag nehezebb és a szövődmények szempontjából kockázatosabb lehet. Az irodalmi adatok azonban biztatóak; a Massachusetts állam Centrumkórházában (MGH) végzett, 846 beteg adatait összegyüjtő vizsgálat szerint a primer és a salvage radikális cystectomián átesett betegek között nem volt szignifikáns különbség a perioperatív mortalitás, a sebészi szövődmények és más, a mütétet gyakran követő komplikációk terén sem. Eswara és mtsai vizsgálatukban a salvage mütéten átesett betegek 16\%-ánál írtak le súlyos (Clavien grade 3-5) szövődményt, emellett 2,2\%-os mortalitásról számoltak be [17]. Donat és mtsai adatai 
szerint a primer radikális mütétet követően a megfeleló értékek 13\% és 2,7\% voltak [9]. Ugyanakkor a szövetek gyógyulásával kapcsolatos szövődmények (például hegszétválás, sebfertőzés vagy a stoma beszúkülése) 35\%ban jelentkeztek, ha a salvage cystectomiát teljes irradiáció után végezték, míg a csökkentett dózis után ezek a szövődmények csak 12\%-ban fordultak elő. Eswara a salvage cystectomián átesett betegeknél ileumconduit képzését javasolja, azonban a sugárterhelést kapott terminális ileum helyett proximálisabban elhelyezkedő bélrészletet használ. Emellett az ileumconduitba ültetendő ureterek besugárzáson átesett distalis végét eltávolították [17].

A betegszelekciónál figyelembe kell vennünk, hogy az SC protokoll szerinti kezelést csak radikális cystectomiára alkalmas, azt szükség esetén elfogadó betegeknél érdemes elkezdenünk. A radikális mútéttől elzárkózó vagy gyengébb általános állapotú betegeknél a kemoradioterápiát megszakító, ellenőrző szövettani mintavételnek nincs terápiás konzekvenciája, hiszen salvage cystectomiát úgysem végezhetünk. Ezért ilyenkor a teljes dózisú kemoirradiációs protokollt kell választanunk [8].

A kezelés után kialakuló recidívákról az irodalomban látott vélemények ellentmondóak, abban azonban megegyeznek, hogy ezek endoszkóposan és lokális terápiás módszerekkel általában jól kezelhetők $[12,18]$. Sanchez és mtsa $i$ vizsgálata szerint a trimodális kezelésre komplett remissziót mutatott betegek 25\%-ánál jelentkezett később nem izominvazív daganatkiújulás, amit az esetek nagy részében transurethralis mútéttel és intravesicalis BCG-instillatióval kezeltek, és ez a betegek 59\%-ában hároméves kiújulásmentes túléléshez vezetett. A kiújulásra adott kezelés tolerabilitása, toxicitása és onkológiai eredményessége nem különbözött jelentősen a korábban irradiációban nem részesült hólyagdaganatos betegeknél tapasztalt eredményektől [12]. Az MGH-ból közölt adatok alapján a cikkünkben bemutatott betegünk számára az öt éven belüli salvage cystectomia esélye 16\% körül van, de még ebben az esetben is várhatóan éveket nyert a radikális mútét következményei és szövődményei nélkül [11].

Lényeges érv a hólyagmegőrző eljárás mellett, hogy az irodalmi adatok szerint a trimodális kezelésben részesült betegek életminősége több tényező tekintetében is szignifikánsan jobb volt, mint radikális cystectomián átesett betegtársaiké. Mak és mtsai hatféle különböző, validált kérdőív (EuroQOL EQ-5D, EORTC Quality of Life Core Questionnaire, EORTC MIBC module, EPIC bowel scale, CTPS, Impact of Cancer, version 2) felhasználásával végzett vizsgálata szerint trimodális kezelést követően a betegek jobb szexuális funkcióról számoltak be, kinézetükkel kapcsolatosan kevesebb aggodalmat éltek át, jobban informáltnak érezték magukat kezelésükkel kapcsolatban, és összességében jobbnak értékelték életminőségüket, mint a radikális mútéten átesett társaik. Az említett kutatásba csak olyan betegeket válogattak be, akik egyébként fizikális statusuk alapján radikális cystectomiára alkalmasnak bizonyultak volna [14].

A trimodális kezelésen átesett betegek megfelelő életminőségének megőrzése szempontjából alapvető fontosságú a kismedencei irradiáció okozta szövődmények minimalizálása. A 2019. évi EAU-ESMO konszenzuskonferencián a húgyhólyagdaganat irradiációja során okozott sugárkárosodás csökkentése céljából az intenzitásmodulált radioterápiát (IMRT) javasolták. IMRT során a célterület nagy intenzitású besugárzása mellett a védendő, ép területek dózisterhelése alacsonyan tartható [19].

A több intézetben zajló, multidiszciplináris kezelés megszervezése tapasztalataink szerint jelentős kihívást jelent. Betegünk esetében szükség volt a sugárterapeuta, az onkológus, az urológiai mútéti team és a patológus munkájának előre megtervezett, pontos összehangolására. Olykor - például az ismételt, ellenőrző hólyagbiopszia alkalmával - egyetlen napra kellett összehangolni a mútétet és a hisztológiai vizsgálatot, valamint a besugárzást. Az összetett kezelés nem csak szervezésbeli problémák miatt maradhat félbe. A két kismedencei besugárzás között elvégzett mintavétel során okozott szövődmény esetén a kemoirradiáció átmenetileg vagy akár végleg megszakadhat. A radiokemoterápia hosszabb felfüggesztése, szüneteltetése sugárbiológiai okokból a kezelés hatékonyságának csökkenésével jár. A bemutatott esetben az onkológiai bizottság ennek veszélyére hivatkozva utasította el első körben az SC trimodális terápia lehetőségét.

\section{Következtetés}

A trimodális terápia sikerében fontos szerepe van a körültekintő betegválasztásnak. Az európai irányelvek szerint ezt a kezelési alternatívát gondosan megválogatott és jól informált betegek esetében érdemes felajánlani. A jó általános állapotú, a radikális cystectomiát szükség esetén vállaló betegek számára onkológiai szempontból az arany standarddal összevethető mértékben biztonságos, a várható életminőség szempontjából pedig nagyon ígéretes alternatíva lehet az SC protokoll szerint végzett trimodális kezelés [6, 12]. Ezeknél a betegeknél ugyanis a kezelés sikertelensége vagy későbbi daganatrecidíva esetén a salvage radikális cystectomia biztonsággal elvégezhetó, ellentétben a nagymütétre eleve alkalmatlan vagy azt kategorikusan elutasító betegtársaikkal $[7,11]$.

A trimodális kezelésre komplett remisszióba kerülő betegeknél a daganat későbbi kiújulása előfordul, ám ezek nagyrészt felületes recidívák, amelyek endoszkópos módszerrel és lokális felületi terápiával megfelelő eredményességgel, a mellékhatások alacsony aránya mellett kezelhetők $[12,18]$.

A kezelés sikeréhez elengedhetetlen a betegutak gondos megszervezése, a mútéti team, az onkológus, a sugárterapeuta és a patológus munkájának pontos összehangolása, mert egyedül a társszakmák szoros, jól 
tervezett együttmúködésével nyílhat meg a gyógyulás felé vezető út. Mivel nem gyakori terápiás megoldásról van szó, célszerü lenne centrum kialakítása és megszervezése a szervmegőrző multimodális kezelés végzésére az uroonkológia ezen területein jártas, tapasztalt szakorvosok részvételével.

Anyagi támogatás: A közlemény megírása anyagi támogatásban nem részesült.

Szerzôi munkamegosztás: F. F., B. K., B. T.: Koncepció, tervezés. Á. P., N. K., G. G., B. T.: A beteganyag rendelkezésre bocsátása. F. F., B. K., B. T.: Adatgyüjtés. F. F., B. K., B. I., B. T.: A kézirat megírása. A cikk végleges változatát valamennyi szerző elolvasta és jóváhagyta.

Érdekeltségek: A szerzőknek nincsenek érdekeltségeik.

\section{Irodalom}

[1] Sükösd F, Iványi B, Pajor L. Accurate determination of the pathological stage with gross dissection protocol for radical cystectomy. Pathol Oncol Res. 2014; 20: 677-685.

[2] Efstathiou JA, Saylor P, Wszolek M. Bladder preservation treatment options for muscle-invasive urothelial bladder cancer. UpToDate Inc., Waltham, MA, Apr 14, 2021. Available from: https://www.uptodate.com/contents/bladder-preservationtreatment-options-for-muscle-invasive-urothelial-bladder-cancer [accessed: July 22, 2020].

[3] Gore JL, Litwin MS, Lai J, et al. Use of radical cystectomy for patients with invasive bladder cancer. J Natl Cancer Inst. 2010; 102: 802-811.

[4] Ritch CR, Balise R, Prakash NS, et al. Propensity matched comparative analysis of survival following chemoradiation or radical cystectomy for muscle-invasive bladder cancer. BJU Int. 2018; 121: 745-751.

[5] Stein JP, Lieskovsky G, Cote R, et al. Radical cystectomy in the treatment of invasive bladder cancer: long-term results in 1,054 patients. J Clin Oncol. 2001; 19: 666-675.

[6] Raj GV, Herr H, Serio AM, et al. Treatment paradigm shift may improve survival of patients with high risk superficial bladder cancer. J Urol. 2007; 177: 1283-1286.

[7] Sylvester RJ, van der Meijden AP, Oosterlinck W. Predicting recurrence and progression in individual patients with stage $\mathrm{Ta} \mathrm{Tl}$ bladder cancer using EORTC risk tables: a combined analysis of 2596 patients from seven EORTC trials. Eur Urol. 2006; 49: $466-477$.

[8] Witjes JA, Bruins HM, Cathomas R, et al. EAU guidelines on muscle-invasive and metastatic bladder cancer. Edn. presented at the EAU Annual Congress, Amsterdam, 2020 (ISBN 978-94-
92671-07-3). European Association of Urology, Guidelines Office, Arnhem, 2020.

[9] Donat SM, Shabsigh A, Savage C, et al. Potential impact of postoperative early complications on the timing of adjuvant chemotherapy in patients undergoing radical cystectomy: a high-volume tertiary cancer center experience. Eur Urol. 2009; 55: $177-185$.

[10] Ploussard G, Daneshmand S, Efstathiou JA, et al. Critical analysis of bladder sparing with trimodal therapy in muscle-invasive bladder cancer: a systematic review. Eur Urol. 2014; 66: 120-137.

[11] Giacalone NJ, Shipley WU, Clayman RH, et al. Long-term outcomes after bladder-preserving tri-modality therapy for patients with muscle-invasive bladder cancer: an updated analysis of the Massachusetts General Hospital experience. Eur Urol. 2017; 71: 952-960.

[12] Sanchez A, Wszolek MF, Niemierko A, et al. Incidence, clinicopathological risk factors, management and outcomes of nonmuscle invasive recurrence after complete response to trimodality therapy for muscle invasive bladder cancer. Urol. 2018; 199: 407-415.

[13] Efstathiou JA, Spiegel DY, Shipley WU, et al. Long-term outcomes of selective bladder preservation by combined-modality therapy for invasive bladder cancer: the MGH experience. Eur Urol, 2012; 61: 705-711.

[14] Mak KS, Smith AB, Eidelman A, et al. Quality of life in longterm survivors of muscle-invasive bladder cancer. Int J Radiat Oncol Biol Phys. 2016; 96: 1028-1036.

[15] Dindo D, Demartines N, Clavien PA. Classification of surgical complications: a new proposal with evaluation in a cohort of 6336 patients and results of a survey. Ann Surg. 2004; 240: 205213.

[16] Arcangeli G, Strigari L, Arcangeli S. Radical cystectomy versus organ-sparing trimodality treatment in muscle-invasive bladder cancer: a systematic review of clinical trials. Crit Rev Oncol Hematol. 2015; 95: 387-396.

[17] Eswara JR, Efstathiou JA, Heney NM, et al. Complications and long-term results of salvage cystectomy after failed bladder sparing therapy for muscle invasive bladder cancer. J Urol. 2012; 187: $463-468$.

[18] Zietman AL, Grocela J, Zehr E, et al. Selective bladder conservation using transurethral resection, chemotherapy, and radiation: management and consequences of $\mathrm{Ta}, \mathrm{Tl}$, and Tis recurrence within the retained bladder. Urology 2001; 58: 380-385.

[19] Horwich A, Babjuk M, Bellmunt J. EAU-ESMO consensus statements on the management of advanced and variant bladder cancer - an international collaborative multi-stakeholder effort: under the auspices of the EAU and ESMO Guidelines Committees. Ann Oncol. 2019; 30: 1697-1727.

(Fazekas Fruzsina dr., Érd, Emőke u. 1/B, 6. em. 26., 2030 e-mail: fazekasfruzsanna@gmail.com)

A cikk a Creative Commons Attribution 4.0 International License (https://creativecommons.org/licenses/by/4.0/) feltételei szerint publikált Open Access közlemény, melynek szellemében a cikk bármilyen médiumban szabadon felhasználható, megosztható és újraközölhetö, feltéve, hogy az eredeti szerző és a közlés helye, illetve a CC License linkje és az esetlegesen végrehajtott módositások feltüntetésre kerülnek. (SID_1) 